\title{
Smoking and mortality from coalworkers' pneumoconiosis
}

\author{
R L Sadler, T J Roy
}

The Medical Research Council Epidemiology Unit has reported at intervals over 30 years on 8526 men initially examined in the Rhondda Fach in $1950 .{ }^{1-4}$ Miners and ex-miners with pneumoconiosis are grouped according to the International Labour Office (ILO) classification in which cases of pneumoconiosis are classified by the appearance on the posteroanterior radiograph. ${ }^{5}$ The small round opacities characteristic of simple pneumoconiosis are classified according to profusion into categories 1,2 or 3. Category $A$ includes those with an opacity or opacities of progressive massive fibrosis of at least $1 \mathrm{~cm}$ with a total diameter not exceeding $5 \mathrm{~cm}$. In category $B$ are one or more opacities with a total area not exceeding that of a third of the right lung, and larger opacities are grouped in category C. Successive MRC reports have been consistent in showing excess mortality in miners and ex-miners compared with non-miners but in miners and ex-miners only those who had category B or C pneumoconiosis showed a raised mortality.

Oldham et al reporting after six years on slateworkers and a control population first examined in 1975 found smoking to be a significant factor in survival. ${ }^{6}$ In slateworkers the risk for smokers was on average $76 \%$ greater than for non-smokers and increased with the severity of pneumoconiosis.

In the Rhondda reports no differentiation is made between smokers and non-smokers but the contribution of tobacco habit to mortality in men with coalworkers' pneumoconiosis is an important consideration. At this centre smoking histories and other data are now available on which such an assessment may be made.

To establish their title to insurance and other benefits, coalworkers with pneumoconiosis have to attend for examination at a pneumoconiosis panel (now, medical boarding centres for respiratory diseases). Lyons et al have shown, by using findings from the National Coal Board's periodic $x$ ray scheme, that most coalworkers with compensatable pneumoconiosis in south Wales are recorded at one of

Medical Boarding Centre (Respiratory Diseases), Swansea SA1 5DF

R L Sadler, T J Roy the pneumoconiosis panels. ${ }^{7}$ Once certified as having pneumoconiosis coalworkers continue to attend these centres for the rest of their lives. Re-examination is at intervals of a few years, men attending in equal numbers throughout the year, so that those examined during one calendar year may be taken as a representative sample of the cases of coalworkers' pneumoconiosis in the region. Records since 1974 have included details of their smoking histories.

The subjects of this investigation are 1193 coalworkers with pneumoconiosis who attended for examination during 1974; six who were diagnosed as having active pulmonary tuberculosis are not included. As the men attended in equal numbers throughout the year the average period of their follow up by 1 January 1975 was six months and by 1 January 1987 , when the survey ended, 12.5 years. To comply with the Registrar General's tables, in which death rates are based on ages at mid-year, their ages are taken to be those at 1 July 1974. Numbers of "expected" deaths are calculated from English Life Tables, $1980-2 .{ }^{8}$ These tables are useful in showing the mortality of a group of men of known ages followed up for a selected period, taking into account the decreasing number of survivors and their increasing ages. Death rates in the life tables are based on three calendar years, $1980-2$, which conveniently fall about the middle of the period here investigated. Expected deaths so derived, however, are based on national death rates and may be no more than an approximation of what could occur among a population of regional coalworkers but they provide a realistic base on which standard mortality ratios (SMRs) of groups having different stages of pneumoconiosis and smoking habits may be calculated and compared one with another. Standard errors of SMRs are calculated by a method described by Cochrane et al. ${ }^{1}$

Smoking histories of the coalworkers are those recorded when they were examined in 1974 . Their average age was then 60 (SD 8.5 years) so that most were approaching or had reached the end of their working lives. SMRs of the men in radiological categories parallel those with pneumoconiosis in the Rhondda survey: mortality is similar in category A and simple cases of pneumoconiosis but considerably higher in B and C categories. Subjects are grouped, therefore, as (a) early pneumoconiosis, which 
Table 1 Standard mortality ratios in non-smokers

\begin{tabular}{lrlll}
\hline Group & No & $\begin{array}{l}\text { Deaths } \\
\text { observed }\end{array}$ & $\begin{array}{l}\text { Deaths } \\
\text { expected }\end{array}$ & SMR (SE) \\
\hline Categories 1, 2, 3 \& A & 193 & 91 & 87.1 & $104 \cdot 5(10.5)$ \\
Categories B \& C & 79 & 51 & 40.9 & $124.7(17.5)$ \\
\hline
\end{tabular}

includes category $A$ and categories 1,2 , and 3 and $(b)$ complicated pneumoconiosis of categories $\mathbf{B}$ and $\mathbf{C}$.

Cigarette smokers are classified as light or heavy smokers depending on whether their consumption was up to or exceeded ten cigarettes a day. Pipe smokers are too few to be separated into light and heavy smokers. Those who used both pipe and cigarettes smoked at least ten cigarettes daily and are included with heavy cigarette smokers. Ex-smokers had ceased smoking for at least one year. The three tables indicate SMRs of the subjects in early and complicated pneumoconiosis groups. In table 1 are non-smokers, table 2 shows SMRs of current smokers according to their tobacco habits, and in table 3 ex-smokers are considered similarly but ex-pipe smokers are too few to allow assessment of their death rate.

\section{Results and comment}

Higher mortality in complicated compared with early pneumoconiosis is evident in non-smokers (table 1), current smokers (table 2), and ex-smokers (table 3 ). Table 2 shows that death rates of pipe smokers are no higher than in non-smokers. In cigarette smokers, however, in both pneumoconiosis groups SMRs are higher than in the non-smokers, the heavy having a higher mortality than the light smokers. Table 3 shows that with early pneumoconiosis the SMRs of all ex-cigarette smokers are lower than those of current cigarette smokers but with complicated pneumoconiosis SMRs of ex-cigarette smokers, both light and heavy, match those of current smokers. This suggests that men with early coalworkers' pneumoconiosis (but not with complicated pneumoconiosis) may reduce their death rate by giving up smoking. The distribution of smoking habits differs in current and ex-smokers, the latter including fewer pipe smokers $(6.9 \%$ compared with

Table 2 Tobacco habit and SMRs in current smokers

\begin{tabular}{|c|c|c|c|c|}
\hline Habit & $\begin{array}{l}\text { No } \\
(\% \text { of total) }\end{array}$ & $\begin{array}{l}\text { Deaths } \\
\text { observed }\end{array}$ & $\begin{array}{l}\text { Deaths } \\
\text { expected }\end{array}$ & $S M R(S E)$ \\
\hline \multicolumn{5}{|c|}{ Categories $1,2,3 \in A$} \\
\hline \multirow{2}{*}{$\begin{array}{l}\text { Pipe } \\
\text { Cigarettes: } \\
\text { Light } \\
\text { Heavy } \\
\text { Total }\end{array}$} & $84(16 \cdot 9)$ & 43 & $41 \cdot 6$ & $103.4(15 \cdot 8)$ \\
\hline & $\begin{array}{l}275(55 \cdot 2) \\
139(27 \cdot 9) \\
498(100)\end{array}$ & $\begin{array}{r}145 \\
64 \\
252\end{array}$ & $\begin{array}{r}113.7 \\
48.2 \\
203.5\end{array}$ & $\begin{array}{l}127.5(10.6) \\
132.8(16.6) \\
123.8(7.8)\end{array}$ \\
\hline \multicolumn{5}{|c|}{ Categories $B \in \mathcal{G} C$} \\
\hline $\begin{array}{l}\text { Pipe } \\
\text { Cigarettes: }\end{array}$ & $36(26 \cdot 7)$ & 20 & $18 \cdot 8$ & $106.4(23.8)$ \\
\hline $\begin{array}{l}\text { Light } \\
\text { Heavy } \\
\text { Total }\end{array}$ & $\begin{array}{c}61(45 \cdot 2) \\
38(28 \cdot 2) \\
135(100)\end{array}$ & $\begin{array}{l}43 \\
26 \\
89\end{array}$ & $\begin{array}{l}29.0 \\
15 \cdot 8 \\
63.6\end{array}$ & $\begin{array}{l}148.3(22.6) \\
164.6(32.3) \\
139.9(14.8)\end{array}$ \\
\hline
\end{tabular}

Table 3 Tobacco habit and SMRs in ex-smokers

\begin{tabular}{|c|c|c|c|c|}
\hline Habit & $\begin{array}{l}\text { No } \\
\text { (\% of total) }\end{array}$ & $\begin{array}{l}\text { Deaths } \\
\text { observed }\end{array}$ & $\begin{array}{l}\text { Deaths } \\
\text { expected }\end{array}$ & $S M R(S E)$ \\
\hline \multicolumn{5}{|c|}{ Categories 1, 2, $3 \in \mathcal{E} A$} \\
\hline \multirow{2}{*}{$\begin{array}{l}\text { Pipe } \\
\text { Cigarettes: } \\
\text { Light } \\
\text { Heavy } \\
\text { Total }\end{array}$} & $15(7 \cdot 3)$ & 6 & $5 \cdot 6$ & \multirow[b]{2}{*}{$\begin{array}{l}118 \cdot 5(17 \cdot 1) \\
119 \cdot 5(17 \cdot 0) \\
118 \cdot 1(11 \cdot 6)\end{array}$} \\
\hline & $\begin{array}{l}81(39 \cdot 1) \\
111(53 \cdot 6) \\
207(100)\end{array}$ & $\begin{array}{r}48 \\
49 \\
103\end{array}$ & $\begin{array}{l}40 \cdot 5 \\
41 \cdot 1 \\
87 \cdot 2\end{array}$ & \\
\hline \multicolumn{5}{|c|}{ Categories $B \in \mathcal{E} C$} \\
\hline \multirow{2}{*}{$\begin{array}{l}\text { Pipe } \\
\text { Cigarettes: } \\
\text { Light } \\
\text { Heavy } \\
\text { Total }\end{array}$} & $5(6 \cdot 2)$ & 5 & $2 \cdot 9$ & \\
\hline & $\begin{array}{l}29(35 \cdot 8) \\
47(58 \cdot 0) \\
81(100)\end{array}$ & $\begin{array}{l}19 \\
30 \\
54\end{array}$ & $\begin{array}{l}13 \cdot 0 \\
18 \cdot 6 \\
34 \cdot 5\end{array}$ & $\begin{array}{l}146.2(33.5) \\
161.3(29.5) \\
156.5(21.3)\end{array}$ \\
\hline
\end{tabular}

$19.1 \%$ ) and more heavy cigarette smokers (54.9\% compared with $28 \%$ ). This distribution is probably self-selective-those whose smoking habit is most contributory to ill health being most likely to become ex-smokers. To compare death rates of groups of smokers and ex-smokers without regard to distribution of smoking habits might be misleading.

The higher mortality associated with complicated pneumoconiosis as compared with that in category $\mathrm{A}$ and simple pneumoconiosis cases ${ }^{1-4}$ is seen in nonsmokers, smokers, and ex-smokers. The radiological extent of progressive massive fibrosis and the smoking habit separately influence mortality. This is evident when comparing the SMRs of all current smokers with early pneumoconiosis (123.8 SE 7.8) and non-smokers with complicated pneumoconiosis (124.7 SE 17.5). In this instance the two factors influence mortality to a like degree.

For permission to make use of department records we are indebted to Dr W R O Eggington, chief medical adviser, Department of Health and Social Security. We are indebted also to Mr John Rees, executive officer, and staff of the centre whose exemplary record keeping made this investigation possible.

Requests for reprints to: Dr T J Roy, Medical Boarding Centre (RD), Grove House, 3 Grove Place, Swansea SA1 5DF.

1 Cochrane AL, Carpenter RG, Moore F, Thomas J. The mortality of miners and ex-miners in the Rhondda Fach. $\mathrm{Br} J$ Ind Med 1964;21:38-45.

2 Cochrane AL. Relation between radiographic categories of coalworkers' pneumoconiosis and expectation of life. $\mathrm{Br}$ Med J 1973;ii:532-4.

3 Cochrane AL, Haley TJL, Moore F, Hole D. The mortality of man in the Rhondda Fach 1950-1970. Br J Ind Med 1979; 36:15-22.

4 Atuhaire LK, Campbell MJ, Cochrane AL, Jones M, Moore F. Mortality of men in the Rhondda Fach 1950-80. Br J Ind Med 1985;42:741-5.

5 International Labour Office. International classification of radiographs. Geneva: ILO, 1970. (Occupational safety and health series No 22.)

6 Oldham PD, Bevan C, Elwood PC, Hodges NG. Mortality of slate workers in north Wales. Br J Ind Med 1986;43:550-5.

7 Lyons JP, Ryder R, Campbell H, Gough J. Pulmonary disability in coalworkers pneumoconiosis. Br Med J 1972;i:713-6.

8 Office of Population Censuses and Surveys. English life tables No 14. London: OPCS, 1987. (Series DS No 7.)

Accepted 5 May 1989 